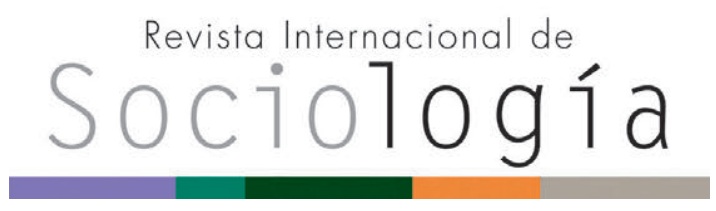

Revista Internacional de Sociología RIS vol. 74 (4), e046, octubre-diciembre, 2016, ISSN-L:0034-9712 doi: http://dx.doi.org/10.3989/ris.2016.74.4.046

\section{DELIBERATIVE PROTESTS? Persuading politicians not to close schools in Swedish municipalities}

\author{
KATRIN UBA \\ Uppsala University \\ Katrin.Uba@statsvet.uu.se
}

Cómo citar este artículo / Citation: Uba, K. 2016. "Deliberative protests? Persuading politicians not to close schools in Swedish municipalities". Revista Internacional de Sociología 74 (4): e046. doi: http://dx.doi.org/10.3989/ ris.2016.74.4.046

\section{¿PROTESTAS DELIBERATIVAS? Persuadiendo a los políticos para que no cierren escuelas en las municipios suecos}

Copyright: (C) 2016 CSIC. This is an open-access article distributed under the terms of the Creative Commons Attribution License (CC BY) Spain 3.0.

Received: 20/12/2015. Accepted: 01/07/2016. Published on line: 21/10/2016

\title{
RESUMEN
}

\section{Abstract}

Studies on the political impact of protest mobilization sometimes show that disruptive protests help social movements achieve their goals. This is conventionally explained by politicians' interests in re-elections and social control, ultimately neglecting alternative arguments such as the drive for better policy solutions. This study investigates if well-reasoned arguments - measured by the deliberative quality of protest letters against school closures - persuade Swedish municipal decision-makers more than simple outcries. Analysis demonstrates support for this argument, as schools defended by protest letters with a higher deliberative quality have higher probability to remain open than schools defended by letters of a lower deliberative quality. However, a fundamental paradox rises from the second conclusion: intrinsically non-deliberate forms of protests, such as demonstrations, have a stronger negative effect on the likelihood of school closures. Hence, well-reasoned communicative practices have some power of persuasion, but experienced activists may prefer disruptive protests for more political leverage.

\section{KEYWORDS}

Letters; Political Process; Reasoned Arguments; Responsiveness; Social Movements.

Los estudios sobre el impacto político de la movilización de protesta muestran que a veces las protestas disruptivas ayudan a los movimientos sociales a alcanzar sus objetivos. Esto se explica convencionalmente por los intereses de los políticos en la reelección y el control social, dejando de lado en última instancia argumentos alternativos tales como la búsqueda de mejores soluciones en términos de mejores políticas. Este artículo investiga si los argumentos bien razonados - medidos por la calidad deliberativa de cartas de protesta contra el cierre de las escuelas - persuaden más que los simples gritos a los responsables municipales en Suecia. El análisis apoya este argumento puesto que las escuelas defendidas por cartas de protesta con una calidad superior de deliberación tienen una mayor probabilidad de permanecer abiertas que las escuelas defendidas por cartas de una calidad deliberativa inferior. Sin embargo, surge una paradoja fundamental a partir de la segunda conclusión: las formas intrínsecamente no deliberadas de protestas, como las manifestaciones, tienen un efecto negativo más fuerte sobre la probabilidad de cierre de las escuelas. Por lo tanto, las prácticas comunicativas bien razonadas tienen cierto poder de persuasión, pero los activistas experimentados pueden preferir protestas disruptivas como medio para obtener más influencia política.

\section{Palabras Clave}

Argumentos Razonados; Cartas; Movimientos Sociales; Proceso Político; Receptividad. 


\section{INTRODUCTION}

Many studies on the political consequences of a social movement's mobilization have shown that activists are more likely to achieve their goals if their protests pose significant costs for decision-makers, their claims enjoy some public support or they have powerful political allies (see reviews in Amenta et al. 2010, Giugni 1998, Uba 2009). Although the mechanisms that explain how and why protests lead to political change continue to be discussed, there are two dominant explanations. The first refers to the electoral interest of decision-makers, who see protests as a signal for changing public opinion (Lohmann 1993). The second explanation refers to social control theories and is related to authorities' interest in stability (Fording 2001). Decision-makers' responsiveness is thereby explained by the coercive power of protests, while the activists' power of persuasion is often neglected (but see Andrews 2001, McCammon 2009). If we assume that politicians are policy seekers as much as they are vote seekers (Ström and Müller 1999), and that social movements could provide these policy seekers with the invaluable information about the benefits of a particular policy proposal (Mansbridge 1992, Burstein and Hirsh 2007), then studies on political consequences of social movements should examine both the coercive and persuasive capacity of protest mobilization.

By focusing on protest letters, and particularly on the deliberative quality of arguments used in these letters, this study investigates how activists opposing school closures in Swedish municipalities achieved their goals. Several prior studies have examined protest mobilization as "communicative practices" (Batel and Castro 2014) and have emphasized that particular framing strategies are needed for movements to achieve their goals (Cress and Snow 2000, McCammon et al. 2007, McCammon et al. 2001, McVeight et al. 2003, Trumpy 2008). Although valuable and important, these studies may not account for the full persuasive potential of activists' claims (cf. McCammon 2009). By focusing on the political and cultural resonance of frames, some specific characteristics of communication, such as openness to dialogue or tone, are left aside. I propose that by using the framework of public deliberation and evaluating the deliberative quality of activists' claims, we can better account for the persuasiveness of these claims and gain a deeper understanding of how social movements achieve political change.

Although coercion via protesting has sometimes been seen as incompatible with the ideals of deliberation (see Mendonca and Ercan 2015), protests could be part of deliberative systems (Parkinson and Mansbridge 2012). As Iris Marion Young (2001:688) explains: "Processes of engaged and responsible democratic communication include street demonstrations and sit-ins, musical works, and cartoons, as much as parliamentary speeches and letters to the editor". Considering that such deliberative communication is expected to result in legitimate policies (Habermas 1996), it is reasonable to expect that wellreasoned arguments should have more persuasive power than simple outcries, in other words protests with little deliberative quality.

This study empirically tests this proposal via a careful analysis of 117 school closure processes in 11 Swedish municipalities during the period of 20002010. Municipal governments often argue that they need to close one or several primary schools because of the declining numbers of pupils or the lack of resources. These proposals are prepared by bureaucrats and then discussed and decided upon by municipal politicians. Very often the proposals face fierce opposition from affected pupils, their parents, teachers, and the local community. Activists use a variety of strategies from sending protest letters to politicians and newspapers to petitions and more contentious actions such as demonstrations or illegal school strikes. Similar conflicts over school closures also take place in the U.S., U.K., New Zealand, Canada, and Germany (Bartl 2015, Basu 2002, Bondi 1988, Witten et al. 2003).

The Swedish right-of-access principle provided the opportunity to get access to all protest letters activists sent to local authorities in the 11 selected municipalities. Hence, it was possible to evaluate their deliberative quality and to systematically relate these letters to the proposals and decisions on school closures. Although Sweden's political system is open to social movements' mobilization (Kitschelt 1986), it is relatively closed to the impact of social movements on national politics (Kolb 2007). At the municipal level, however, the openness of the Swedish political structure to the impact of social movements is comparable to that of other countries. Hence, the results presented in this study may also be applicable outside of Sweden and in other cases of local level conflicts, such as windmill construction or hospital closures.

\section{THE POWER OF PERSUASION AND COERCION}

Social movements participate in the process of public deliberation. They can put direct pressure on decision-makers by using various forms of protests, but they can also try to convince decision-makers of the merits of their policy proposals. Social movements have the power of coercion and persuasion (Andrews 2001). While coercion is related to the disruptive character of protest events - demonstrations, strikes or riots, persuasion is related to the arguments used by activists during a mobilization. Although both aspects are important for achieving political and social change, prior theoretical developments and empirical analysis have more frequently focused on the aspect of coercion (reviews in Amenta et al. 2010, Bosi et al. 2016). 
The studies that focus on the persuasive capacity of social movements use mainly the framing approach (e.g., Cress and Snow 2000, McVeight et al. 2004). Framing in this context is defined as a discursive process of strategic actors using symbolic resources to participate in collective sense-making with regard to public policy issues (Gamson 1996). Frames are "a set of interpretative packages that give meaning to an issue" (Gamson and Modigliani 1989:3). Social movements can use a variety of frames and these could also change over time. Sometimes movements use only a diagnostic frame, which refers to the problem and the actors to blame, while at other time points of diagnostic frames are combined with prognostic frames, which explain what needs to be done in order to remedy the current problem (Benford and Snow 2000). The framing process is important for mobilization, as well as for achieving social and political change. It has been shown that coherent and well-articulated diagnostic and prognostic frames help movements attain their goals if there is some cultural and political resonance between the frames used by movements and the existing frames (Cress and Snow 2000, McCammon et al. 2007, McCammon et al. 2001, McVeight et al. 2003). Resonance means that the frames must relate to decision-makers' core beliefs, values and attitudes.

Although cultural and political resonance are important, communicative practices such as protest letters also have other characteristics that might make some protest letters more persuasive than others. For instance, in lobbying literature it is widely acknowledged that advocacy groups provide decisionmakers with information otherwise unavailable (Dür 2008), and such information is positively related to advocacy groups' goal attainment in the case of school closures (Larsson Taghizadeh 2015). Studies on political communication add that the way of presenting this information also matters, as framing information as a credible argument improves persuasiveness of the message (Chong and Druckman 2007). The same is found by research on deliberative democracy and opinion formation (Gerber et al. 2014, Gross 2008). Therefore, in order to better explain how social movements achieve their goals we must go beyond the analysis of diagnostic and prognostic frames and examine how well-reasoned the movements' arguments are and how this relates to their political achievements.

McCammon (2009) adopted a similar approach for evaluating the persuasive capacity of the women's jury movements in the U.S. She found empirical evidence for an argument that a movement's frames that (1) show the problem as a serious one and having broad social consequences, (2) are well articulated and include a "because" clause, and (3) have empirical credibility have more persuasive power than messages without such qualities (McCammon 2001:59).
This approach is a great step further, but it neglects some aspects of communication that are considered particularly important in the studies of deliberative democracy, namely the idea of consensus formation and search for a common good (see Mansbridge et al. 2006). Hence, in addition to rationality, which could be measured as well articulated or well reasoned arguments, the legitimacy and thereby persuasiveness of protest messages also requires the proposal of alternative solutions, all of which should be presented in a way that opens dialogue (Öberg and Uba 2014).

This proposal might seem unexpected for those familiar with the antagonism between protests and the process of deliberation (see review in Dodge 2015). An activist could be rather similar to a deliberative democrat in his longing for justice, but in contrast to a deliberative democrat he is often angry, frustrated, and would opt for other tactics than discussing argumentatively with the policy-makers (Younf 2001). This might be true on many occasions, but several recent empirical investigations have demonstrated that activists can use well-articulated and well-reasoned arguments (Dodge 2015, McCammon 2009). Especially in the case of protests against school closures, Öberg and Uba (2015) demonstrated that activists use protest letters with varying degrees of deliberative quality. The last was measured through well-reasoned arguments, supporting these arguments with a legitimate source (official document, media or academic publication), providing alternative solutions to the problem at hand, using a friendly tone and being open to dialogue. Considering this and the presented prior studies on political consequences of a social movement's mobilization, I expect to find that the protests against school closures are more likely to attain their goals if activists use arguments that have a high degree of deliberative quality.

However, policy-makers are vote seekers as much as policy seekers and therefore protesting could also influence policy-makers thanks to its coercive character. It has been shown that activists whose protests generate higher disruption costs have a higher likelihood to achieve their goals (Luders 2010). In contrast to being persuaded by the better argument, decisionmakers rationally compare the costs of disruption, that is the damage caused by protests or the loss of votes in future elections, with the costs of concession. The costs of concession, in turn, are dependent on specific policy decisions. In the case of school closures it would mean that local authorities keep the school open and cover the related economic costs. This might mean cuts in some other areas or a tax rise. Thus, the disruptive or costly protests such as demonstrations, strikes or large petitions might achieve political change even though these actions tend to present claims with low deliberative quality. Therefore, mobilization demonstrations, strikes or large petitions will be accounted for in the following analysis. 
While movement activism plays an important role in the process of policy change, the political consequences of social movements are dependent on political context (Amenta et al. 2010). Having political allies, that is enjoying support of a political party in power, increases the political influence of the movements (Giugni 2005, Meyer and Minkoff 2004). Similarly, public support for a movement's goals has also been shown to increase the likelihood of achieving those goals because the electoral costs of such mobilization are higher (Amenta et al. 2005, Burstein and Linton 2002, Uba 2009). Public support for movements' claims is important for sustaining mobilization, but movements can also gain public support as a result of mobilization and this might amplify the political impact of mobilization (Agnone 2007). Although allies and public opinion are potentially important for the mobilization against school closures or the decisions regarding school closures, these will not be accounted for in the following empirical analysis for two reasons. Firstly, there was no single political party seen as an ally to activists against school closures in the Swedish municipalities. Opposition parties often opposed closures, but as soon as the party came to power the disapproval of anti-school protests among the politicians increased regardless of the ideological leaning of their party (Uba 2016). Secondly, considering the numerous protests against school closures in Sweden since the early 1990s (Ibid.), there is probably a general public opposition to school closures, and therefore it is likely that activists enjoy public support regardless of the school or municipality of interest.

In addition to allies and public opinion, there are also more structural factors such as the political opportunity structure, which influences social movements' ability to achieve policy change (Amenta et al. 1992, Kriesi et al. 1995, Kolb 2007, Meyer and Minkoff 2004). The Swedish political system is said to be relatively open to social movement mobilization (Kitchelt 1986) and relatively closed to the political impact of social movements at the national level (Kolb 2007). However, the traditional characteristics of political opportunity structure, such as federalism, bicameralism, executive-legislative relationship, are rather used for comparing countries than municipalities. Eisinger (1973), in his classical study of protests and political opportunities, suggested that the formal structure of local governments (cities) is to be accounted for, but there would not be any variation of that structure in the Swedish case (Bäck 2008).

However, other factors such as the closeness of elections could encourage protest mobilization, as well as make the local authorities more vulnerable to changes in the public mood (Burstein and Linton 2002). Hence, this, as well as other factors that might affect the decisions on school closures, should be accounted for in the study of protest im- pact on policy change, and are further discussed in the section introducing the control variables used in the empirical analysis.

\section{The CASe of SCHOOL Closures in Sweden}

The major wave of school closures started in Sweden in the early 1990s, just after municipalities received the right to make decisions on school financing. Since then local authorities have closed about 600 schools and threatened to close a further 1245 schools, and the process has faced more than 1300 protest events. Municipal authorities propose school closures because of economic difficulties, decreasing number of pupils, or problems with the quality of teaching (Björklund et al. 2004). The schools threatened with closure are identified by bureaucrats, but local politicians who have a seat in school committees or educational affairs make the final decision. The committees include representatives from all political parties that have a seat in local parliament, and the power balance is the same as in local parliament. The head of the committee comes from the governing party and as the decision affects the budget of the municipality, the entire municipal parliament can vote in favor or in opposition of the proposal.

The process usually takes time as the affected parties - the teachers, pupils and their parents - need to be informed of the changes such as the name of the new school or the changed modes of transportation. Parents, pupils and teachers usually learn about the proposal or the threat of closure directly from school representatives or via the media. Protests against the proposal are, as noted, frequent, and often motivated by parents' unwillingness to send their children to larger schools further away. The strategies involve demonstrations and illegal school strikes, in other words refusing to send pupils to school, as well as petitions, letters and emails sent directly to the responsible committee.

This study is based on the cases of 118 threatened schools from 11 municipalities, of which 67 $(57 \%)$ were closed by the end of 2010 . Ideally, one would examine all 290 Swedish municipalities that proposed and implemented school closures since 1991, but due to practical reasons only 11 municipalities ${ }^{1}$ were chosen. Considering that the selected municipalities include both smaller and larger municipalities, larger cities (Gothenburg), and mainly rural areas (Falun), the selection bias should be relatively small. Looking at the political rule of these municipalities, there are those traditionally ruled by Social Democrats (Falun), as well as those where the incumbent coalition has changed after the elections in 2002 or 2006 (e.g., Uppsala).

Data on schools threatened with closure and those closed in the selected municipalities were collected within the framework of a larger research project 
and involved two processes (see Larsson Tagizadeh 2016, Uba 2016). Firstly, every Swedish municipality was asked to report the list of schools they have threatened to close, and provide information on the year of the proposal and the schools' closure, if that was the case. Only $60 \%$ of the municipalities responded, and therefore the same information was searched for in Sweden's national and local newspapers, national newswire (TT), public TV and radio, as well as municipal websites. This process also gave us information about the protests related to these particular proposed closures. It was only in the case of 38 schools (32\%) out of the examined 118 schools that we did not find any information about visible protests such as petitions, protests during public meetings with policy-makers, demonstrations or school strikes. The rest of the schools had at least one protest event, and four schools (Brantingskola, Mellringeskola, Norrehedskola, and Gustav Adolf school) had more than six protests. The main activists were pupils, their parents and on fewer occasions teachers or small village organizations. Petitions, letters to newspapers and protests in public meetings dominated, but there were also 20 more disruptive events such as demonstrations (12), illegal school strikes (5), and large petitions (3).

Traditional studies on the political influence of social movement mobilization would have stopped here and focused only on visible protest events. This might be misleading not only because media-based protests data suffer from several biases (Ortiz et al. 2005), but because activists often turn to authorities via direct (invisible) channels such as letters, emails, petitions or phone calls. This obviously depends on the case and country, but in Sweden the tradition of contacting policy-makers, especially at the local level, is very strong (Kriesi and Westholm 2007). Consequently, all 11 municipalities were contacted a second time, requesting all material activists had sent them with regard to school closures (see Larsson Tagizadeh 2016). This resulted in 324 letters, postcards, emails, and petitions, which were sent in against the proposed closure of 55 different schools (16 petitions, 160 shorter emails and letters, 148 longer emails or letters). The majority of the letters were sent by one individual or family (42\%), while neighborhood groups and other civil society organizations sent in about $29 \%$ of the letters, and school teachers and personnel sent about $7 \%$ of the letters. While letters generally do not differ much across these groups, there are two interesting patterns: pupils tend to send postcards and drawings, and community groups often send long letters with a detailed analysis.

The letters are not equally distributed between these 55 schools. While Karlslundsskola in Örebro municipality had 32 letters, the average number per school was eight and seven schools only had one letter. Interestingly, for 10 out of these 55 schools we did not have any information about the visible protests. This demonstrates the bias scholars might have when relying only on newspaper data on protest actions. On the other hand, for 34 schools for which we had recorded some information about visible protests, the municipalities had not received or archived any protest letters. The case clearly shows the importance of triangulation of data sources for protest event analysis, previously emphasized by many scholars (see e.g., Hutter 2014). Due to these differences in data, but also due to the fact that disruptive protests tend to bear slogans rather than well-reasoned arguments, the empirical analysis of protests' impact on politicians' decisions over school closures uses two sets of schools: all 118 schools and the 55 schools that received at least one protest letter. The last set is more useful for evaluating which letters those with higher or lower deliberative quality - have more political leverage.

\section{Measuring the deliberative quality OF PROTEST LETTERS}

One research assistant carefully read and analyzed the content of all 324 letters that opposed the proposed closure of a particular school or schools. ${ }^{2}$ Some authors just stated their opposition, others asked for further investigations, and a few provided a list of alternative proposals. The letters that were sent to a municipality after politicians had decided on a closure are not included, as these cannot influence the decision. The deliberative quality of the letters is evaluated on the basis of the method proposed by Öberg and Uba (2015). They suggest that a letter has a high deliberative quality if it: (1) uses well-reasoned arguments; (2) uses any reference to some official document or media source for legitimating these arguments; (3) presents alternative solutions; (4) uses a friendly tone; and (5) is open for discussion.

The first criterion simply measures whether the protest letter includes any reasoned arguments in addition to the stated opinions or if it is a simple outcry. A small proportion, about $9 \%$, of all letters did not include any reasoned arguments and just stated: "We want to keep the Alby-school!" (ID1); "Please do not close Jakobgårds-school!" (ID102); or "Save the school in Kortedala!" (ID345). Sixty percent of the letters included one to four clearly stated arguments, and the remaining $30 \%$ listed more than five arguments against the proposed school closure. The arguments varied but usually involved some diagnostic and prognostic framing, and referred to different perceived consequences of the process.

For instance, about one-fifth of the letters explained that pupils would face higher risks related to traffic and would have long traveling times to and from school: "The proposal means that our children must daily cross the railway and a very busy road." (ID 50); "The proposal means that I have to say 
... Goodbye to my children who will die in the next dreadful bus accident! No!" (ID 403); or "The schools must remain! Otherwise all children need to take a bus to school!" (ID46).

Other common arguments referred to: the quality of education and larger classes - "Have you really thought about 'overpopulating' other schools, which already suffer from too many pupils, with children from [X]-school?" (ID 74); loss of village center and negative effects for the rural community - "We need the $[X]$-school to keep our village alive and for the security of all children who live today and will live in the region in the future!" (ID 58); or to lacking democracy in the decision-making procedures - "The decision is being rushed, seemingly only because you want to minimize the number of protests!" (ID 67). Many letters combined different arguments, but from the perspective of deliberative quality we measured only on the presence or lack of reasoned arguments.

The second criterion requires that activists support their arguments with some legitimate source of information such as their own investigation, official documents or media reports (Öberg and Uba 2015). The information provided by activists might be something decision-makers have not considered before (e.g., new economic calculations), but they also might provide new interpretation of existing knowledge. About onethird of the letters supported their arguments by referring to a legitimate source, be it their own investigation or official documents. For example, an argument about traffic safety was legitimized by referring to a national road agency: "According to the Swedish Road Administration almost half of the accidents involving children take place when they cross the road" (ID 200).

The third criterion requires the presentation of alternative proposals, which is important because bureaucrats and policy-makers often present their arguments as if there were no other alternative to closure. The proposed alternatives varied from statements such as "Demolish school B instead; it is in a bad shape anyway!" (ID180) to some more constructive ones like "Integrate a pre-school with our school and thereby save it!" (ID 411). About $36 \%$ of the letters included some alternative proposals.

Finally, we had to collapse the fourth and fifth criterion because letters that had a friendly tone were also open for a dialogue. The tone of the examined letters varies from that of polite and bureaucratic formulations to hate letters and emotional pleas. For example: "For God's sake, do not close the [X]school, the decision is hasty and unconsidered!" (ID 118); "Hi you bloody politicians! ... We hate you!" (ID 203); or "Please, please save our school!" (ID 36). Although recent studies on deliberative systems are more open to the use of emotions in the process of deliberations (Mansbridge et al. 2006), I would argue that a friendly tone refers to more equality, inclusiveness and search for consensus rather than an upset or threatening tone. Many letters used threats such as stating that activists would never vote for governing politicians or for their party, threatening to move to another municipality or to open a new independent school. In total, about $54 \%$ of all letters had a friendly tone and were open for a dialogue.

As a result of the content analysis, it was possible to calculate an additional index of deliberative quality for every examined letter. The index (DI) varies between 0 to 4 , where 0 refers to a letter without any arguments, 1 to a letter with at least one or more arguments, 2 to a letter with arguments supported by a source, 3 to a letter with arguments, source, and alternative, and 4 to a letter with arguments, source, alternatives and friendly tone/openness to dialogue. In many cases there were several letters per school, and therefore every school got its aggregate mean value of deliberative index. Three schools had letters with the lowest level of deliberative quality (0), while six schools achieved the maximum value (4), and the average deliberative index for all 55 schools was 2.63. If we assume that other protest actions present messages with low deliberative quality, then among all of the 61 schools that had at least one protest event or at least one protest letter, the average deliberative quality is a bit lower -2.12 .

\section{Control VARIABles}

It was noted above that the structure of local government, political allies and public support for activists against school closures in Sweden is likely to be the same across the municipalities and threatened schools. Although some local politicians agreed with activists and supported their claims against the proposed closure, no single political party dominated. The issues appeared to be more pragmatic than ideological. When the Social Democratic Party proposed a closure in one municipality, it opposed it in another, due to the fact that it was in opposition in the latter. The same applied to the Conservative (Moderaterna) or Liberal party (Folkpartiet). Local politics in Sweden do not have to follow the national trends, and therefore there are municipalities where Social Democrats cooperate with the Center Party, although at the national level the parties belong to different coalitions. With respect to public opinion, there is currently a lack of opinion poll data about the issue, but the numerous protests against the proposed closures suggest that the public is more opposed to than in favor of the closures.

One political context variable is however included and this relates to elections. It is likely that schools proposed for closure during election years have a higher probability to remain open due to increased political conflict, and it is also easier to mobilize protests during times of high instability (Meyer and Minkoff 2004). During the examined period of 2000-2010, there were three municipal elections: 2002, 2006 and 2010. Of all the 118 schools, 24 (20\%) were threatened during 
one of these years. Ideally one would also take into account many socio-economic details about the municipalities, but considering the relatively few numbers of units of analysis it is important to keep the number of variables low. Hence, I simply opt for a simple model that accounts for the intra-municipal variation by using clustered standard errors.

The characteristics of schools might affect protest mobilization as well as the decisions on school closures. Therefore the analysis includes two school related variables. Firstly, the distance of the school threatened with closure from the closest remaining school (in kilometers). Closing a school in a remote area means longer traveling times for pupils and could be a strong incentive for mobilization. Similarly, the costs of transportation might be relatively high in comparison to the savings the municipality earns from closing the school premises. The distance between the threatened and the closest remaining school is calculated with the help of GPS coordinates for all schools in the examined municipalities, not only those threatened by closure, and the lists and addresses are taken from the Swedish School Board's database. Distance varies from 23 meters to 31 kilometers and has an average of $2.63 \mathrm{~km}$.

Smaller schools should be easier to close as fewer pupils need a place in new schools, and one can expect that the opposition to closure by parents is also smaller. Prior studies have shown that Swedish municipalities often close small rural schools because of economic reasons or due to the lack of pupils and children in the area (Åberg-Bengtsson 2009). However, the number of pupils in the schools threatened with closure ${ }^{3}$ has a very strong correlation with the school's distance from the remaining school. As the distance is a more accurate measure than the num- ber of pupils, the following analysis only accounts for the distance between the threatened and the closest remaining school.

The second school-specific variable indicates whether the schools were supposed to be closed entirely or only partially, that is only some classes were planned to be closed. Information comes from the same source as the information about the closures. Out of 118 schools, 20 were proposed to be closed only partially $(17 \%)$.

Finally, protest letters are not the only form of mobilization against proposed school closures, and as was noted above activists also used other forms of protests. Disruptive events were expected to have more political leverage than non-disruptive protests, and therefore we use a dichotomous measure that takes into consideration if any demonstrations, strikes or very large petitions (more than 1,000 signatures) were used against the closure of the particular school. There are 20 such schools (17\%) in our full set of 118 schools, while 14 in the sample of 55 schools had at least one protest letter.

\section{Results AND DISCUSSION}

The analysis is done with the help of simple logistic analysis that accounts for the fact that schools are nested in 11 municipalities by clustering standard errors. The dependent variable is a dichotomous measure of whether the school was open (0) or closed (1) at the end of $2010 .{ }^{4}$ The goal is to test whether the deliberative quality of the protest letters and disruptive protests relate to the probability of closure when we account for the above-listed control variables. Table 1 presents the results of four different models.

Table 1.

Probability of school closures (maximum likelihood coefficients from a logit analysis)

\begin{tabular}{lllll}
\hline & Baseline & $\begin{array}{l}\text { Baseline } \\
\text { protests }\end{array}$ & $\begin{array}{l}\text { Schools with } \\
\text { at least one } \\
\text { protest }\end{array}$ & $\begin{array}{l}\text { Schools with at } \\
\text { least one protest } \\
\text { letter }\end{array}$ \\
\hline Distance $(\mathrm{km})$ & $-0.10(.05)^{*}$ & $-0.12(.06)^{\star *}$ & $-0.15(.09)$ & $-0.13(.09)$ \\
\hline Partial closure & $-0.45(.38)$ & $-0.41(.40)$ & $-0.56(.52)$ & $-0.89(.50)$ \\
\hline Election year & $1.58(.55)^{* *}$ & $1.60(.55)^{\star *}$ & $0.99(.72)$ & $0.64(.79)$ \\
\hline Any disruptive protests & & $-1.03(.32)^{\star * *}$ & $-1.33(.54)^{\star *}$ & $-0.88(.73)$ \\
\hline $\begin{array}{l}\text { Deliberative quality of } \\
\text { protest letters }\end{array}$ & & & $-0.29(.27)$ & $-0.85(.20)^{\star * *}$ \\
\hline
\end{tabular}

\begin{tabular}{lllll}
\hline Constant & $0.37(.27)$ & $0.60(.32)^{\star}$ & $1.41(.72)^{\star}$ & $2.98(.95)^{\star *}$ \\
\hline Pseudo $\mathrm{R}^{2}$ & 0.08 & 0.10 & 0.12 & 0.17 \\
\hline $\mathrm{N}$ & 118 & 118 & 61 & 55 \\
\hline
\end{tabular}

Note: ordinary logistic model with clustered standard errors for 11 municipalities, numbers in parentheses are standard errors, ${ }^{* * *} p<0.001,{ }^{* *} p<0.01,{ }^{*} p<0.05$ 
The first three models use all 118 schools and the fourth model uses only the limited set of the sample, which are the schools that have at least one protest letter. The first baseline model demonstrates that the probability of school closures is related to distance from those schools remaining open. Interestingly, the effect of elections is unexpected, as schools that were threatened by closure during the municipal elections years (2002 or 2006) are more likely to be closed than to remain open. National elections in Sweden are held on the same day (in early September) as municipal elections. The reason for the aforementioned negative effect might be the fact that several schools were threatened with closure before September and these were quickly closed, probably in order to avoid election-related discussions and possibly because the party in power might lose its incumbent position as a result of the elections. This was the case for 17 of the 20 schools that were threatened during the election years. More detailed information about the dates when the decision to threaten and close a school would take place is necessary for outlining whether the closures took place before or after elections. Nevertheless, such fast processes also decrease the opportunities for activists to protest.

The second model adds the variable of disruptive protest events for measuring the effect of coercion on school closures. It demonstrates that there is a clear negative effect of disruptive protests, as the schools that were defended by strikes, demonstrations or very large petitions have a lower probability to be closed. I have also tested to check if disruptive and non-disruptive protests have a similar negative effect on closures, but there was no support for this model (results are not shown, but available upon request). Demonstrations, strikes and large petitions that constitute disruptive strategies in this study were also used in combination with other less disruptive forms of protests. Hence, the effect of this variable could also refer to the importance of intensity of protests. The results are similar to findings of several prior studies, which show that disruptive tactics help movements attain their goals (Piven and Cloward 1979, Gamson 1990, Luders 2010).

The third model adds the deliberative quality of the protest letters. All schools that received no protest letters have the value zero for this variable, and here it is important to limit the sample of schools to those having at least one protest action (61 schools of 118). There is no significant relationship between closures and the quality of deliberation, while the effect of disruptive protests continues to be significant. The results are the same if we use the full sample of 118 schools. This suggests that in the case of school closures the coercion or the electoral costs imposed by the activists are more important than the persuasion.

Still, if activists choose to send protest letters, what kinds of letters are the most persuasive? The final model in Table 1 provides the answer and the results are also portrayed in Figure 1. Schools that were defended by the letters with a higher deliberative quality have a significantly lower probability of closure than the schools without such letters. This is in accordance with the results presented by McCammon (2009) for a very different movement and country, and suggests that well-reasoned arguments presented with some legitimizing source, which also propose alternative solutions to the problem and present it in a way that allows for dialogue have more persuasive capacity than simple statements of opposition or outcries. Using highly deliberative arguments does not always guarantee the attainment of activists' goals, but the probability to achieve the goals is twice higher if outcry is replaced by reasoning, friendly tone and alternative arguments (see Figure 1). As protest letters could be used together with disruptive events such as demonstrations, I even tested the probable interaction effect. However, when activists use both disruptive protests and messages with a high deliberative quality, this does not have any significant effect on school closures (model not shown, but available upon request). Hence, it seems likely that the mechanisms of coercion and persuasion do not work simultaneously; rather they are independent from each other.

Figure 1.

Probability of school closure and deliberative quality of protest letters

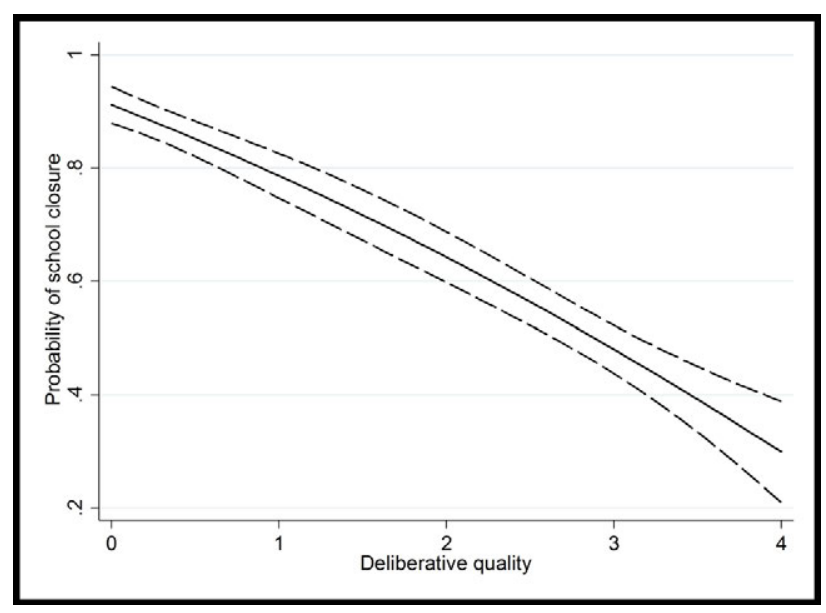

\section{Conclusion}

The results of this study might be seen as tentative, due to the limited number of units in this analysis and because the case of school closures in Sweden may be a relatively specific one. On the other hand, the process of school closures does not differ greatly from other cases which involve various local level conflicts, such as the placement of energy projects (McAdam and Boudet 2012). Hence, the results give us a good reason to expect that the deliberative quality of protest messages increases the activists' persuasive power. This advances our understanding of 
the political consequences of social movement mobilization, as previous studies have mainly focused on disruption (coercion) or framing of the argument, but neglected the fact that social movements or protest activists can provide important knowledge for policy seekers in a convincing way. Protest letters that include arguments that are supported by some legitimate source, provide alternative solutions, and use a friendly tone are more persuasive than letters without such qualities.

It is an important finding in two respects. Firstly, it supports the argument that protesting and deliberation do not have to be seen as opposed, and moreover, that protesting might also lead to some insights with regards to deliberation (Dodge 2015). Secondly, and more importantly for the research on political consequences of social movement mobilization, we must pay more attention to deciphering the persuasive power of protests. Some studies have proposed that persuasion is important (e.g., Andrews 2001) but have only been able to measure it as a frequency of contacts or strength of the organizations or move-

\section{AcKNOWLedgments}

I would like to thank Lisa Magnusson and Simon Magnusson for all research assistance and anonymous reviewers for their helpful comments. The writing of this article has benefited from a generous funding of the Swedish Riksbankens Jubileumsfond (project number P09-1020:1-E).

\section{Notes}

1. The selected municipalities are Boras, Borlänge, Botkyrka, Falun, Gävle, Göteborg, Helsingborg, Kalmar, Lund, Örebro, and Uppsala. While Sweden has 290 municipalities, only 273 of them have closed or threatened any schools with a closure.

2. The coding scheme was developed and tested by the author and the assistant, although the coding of letters was carried out by the assistant only and therefore no tests for intercoder reliablity have been made. All questionable cases were discussed, and this should increase the reliability of the coding.

\section{References}

Åberg-Bengtsson, L. 2009. The smaller the better? A review of research on small rural schools in Sweden. International Journal of Educational Research, 48(2), 100-108. http://dx.doi.org/10.1016/j.jjer.2009.02.007

Agnone, J. 2007. Amplifying public opinion: The policy impact of the US environmental movement. Social Forces, 85(4), 1593-1620. http://dx.doi.org/10.1353/sof.2007.0059

Amenta, E., Caren, N., Chiarello, E., \& Su, Y. (2010). The political consequences of social movements. Annual Review of Sociology, 36, 287-307. http://dx.doi.org/10.1146/annurev-soc-070308-120029 ments. This study has, however, demonstrated that that we learn more about the persuasive qualities of protesting when examining the claims and, more importantly, the way these claims are formulated.

Although activists, as well as politicians, often use claims with a low deliberative quality, we need to further examine in which context the use of wellreasoned arguments may help movements to attain their goals. Is it only a characteristic of a relatively open welfare state such as Sweden, of fairly minor local questions such as school closures, and of cases where the public in general supports activists' goals, or does the activists' use of deliberative claims also benefit the environmental or civil right movements in other countries? More research focusing on a dialogue between activists and decisions-makers would trace the development of these arguments. It could also show whether the decision-makers pick up the arguments presented by the activists and if that eventually relates to the attainment of a movement's goals. This would be an important leap toward the demonstration of causality in protests' impact.
3. I reviewed the average number of pupils in all 118 schools in 2002 or the closest year for which the numbers were available in the Swedish School Board's database. The number of pupils varies from 14-647.

4. It is important to recall that we examined the closure decisions, not the real implementation, as sometimes the implementaton of the decision might require time. Municipalities avoid implementing their decisions in the middle of the school year, but they can easily decide on the closure in September.
Amenta, E., Caren, N., \& Olasky, S. J. 2005. Age for leisure? Political mediation and the impact of the pension movement on US old-age policy. American Sociological Review, 70(3), 516-538. http://dx.doi.org/10.1177/000312240507000308

Andrews, K. T. 2001. Social movements and policy implementation: The Mississippi civil rights movement and the war on poverty, 1965 to 1971 . American Sociological Review, 71-95. http://dx.doi.org/10.2307/2657394

Bäck, H. 2008. Intra-Party Politics and Coalition Formation Evidence from Swedish Local Government. Party Politics, 14(1), 71-89. http://dx.doi. org/10.1177/1354068807081818 
Bartl, W. 2015. Coping with Demographic Decline in German and Polish Municipalities. In Coping with Demographic Change: A Comparative View on Education and Local Government in Germany and Poland (pp. 95130). Springer International Publishing. http://dx.doi. org/10.1007/978-3-319-10301-3_6

Basu, R. 2007. "Negotiating Acts of Citizenship in an Era of Neoliberal Reform: The Game of School Closures." International Journal of Urban and Regional Research, 31(1): 109 127. http://dx.doi.org/10.1111/j.1468-2427.2007.00709.x

Benford, R. D., \& Snow, D. A. 2000. Framing processes and social movements: An overview and assessment. Annual review of sociology, 611-639. http://dx.doi.org/10.1146/annurev.soc.26.1.611

Bondi, L. 1988. Political participation and school closures: an investigation of bias in local authority decision making. Policy \& Politics, 16(1), 41-54. http://dx.doi.org/10.1332/030557388782455136

Bosi, L. Giugni, M. and Uba, K. 2016. Introduction. In Bosi, Lorenzo, Marco Giugni, and Katrin Uba, eds. The Consequences of Social Movements. Cambridge University Press http://dx.doi.org/10.1017/CBO9781316337790

Burstein, P. (2014). American Public Opinion, Advocacy, and Policy in Congress: What the Public Wants and what it Gets. Cambridge University Press.

Burstein, P. 1998. Bringing the public back in: should sociologists consider the impact of public opinion on public policy? Social forces, 77(1), 27-62. http://dx.doi.org/10.2307/3006009 / http://dx.doi. org/10.1093/sf/77.1.27

Burstein, P., \& Hirsh, C. E. 2007. Interest Organizations, Information, and Policy Innovation in the US Congress1 2. Sociological Forum, 22(2):174-199. http://dx.doi.org/10.1111/j.1573-7861.2007.00012.x

Chong, D., \& Druckman, J. N. 2007. Framing public opinion in competitive democracies. American Political Science Review, 101(04), 637-655. http://dx.doi.org/10.1017/S0003055407070554

Cress, D. M., \& Snow, D. A. 2000. The outcomes of homeless mobilization: The influence of organization, disruption, political mediation, and framing. American Journal of Sociology, 1063-1104. http://dx.doi.org/10.1086/210399

Dodge, J. 2015. The deliberative potential of civil society organizations: framing hydraulic fracturing in New York. Policy Studies, 36(3), 249-266. http://dx.doi.org/10.1080/01442872.2015.1065967

Eisinger,P.K.1973. TheconditionsofprotestbehaviorinAmerican cities. American political science review, 67(01), 11-28. http://dx.doi.org/10.2307/1958525

Fording, R. C. 2001 The political response to black insurgency: A critical test of competing theories of the state. American Political Science Review, 95(1):115-130.

Gamson, W. A. 1990, 1975. The strategy of social protest. Homewood, IL: Dorsey Press.

Gamson, W \& Modigliani 1989 Media discourse and public opinion on nuclear power: A constructionist approach. American Journal of Sociology, 95 (1):1-37. http://dx.doi.org/10.1086/229213

Gerber, M., Bächtiger, A., Fiket, I., Steenbergen, M., \& Steiner, J. 2014. Deliberative and non-deliberative persuasion: Mechanisms of opinion formation in EuroPolis. European Union Politics, 15(3), 410-429. http://dx.doi.org/10.1177/1465116514528757

Giugni, M. 2004. Social protest and policy change: Ecology, antinuclear, and peace movements in comparative perspective. Rowman \& Littlefield.
Gross, K. 2008. Framing persuasive appeals: Episodic and thematic framing, emotional response, and policy opinion. Political Psychology, 29(2), 169-192. http://dx.doi.org/10.1111/j.1467-9221.2008.00622.x

Habermas, J. 1996. Between facts and norms. Cambridge: Polity Press.

Hutter, S. 2014. Protesting economics and culture in Western Europe: new cleavages in left and right politics. University of Minnesota Press. http://dx.doi.org/10.5749/ minnesota/9780816691180.001.0001

Kitschelt, H. P. 1986. Political opportunity structures and political protest: Anti-nuclear movements in four democracies. British journal of political science, 16(01), 57-85. http://dx.doi.org/10.1017/S000712340000380X

Kolb, F. 2007. Protest and opportunities: the political outcomes of social movements. Campus Verlag.

Kriesi, H. and Westholm, A. 2007. "Small-scale democracy: the determinants of action." In Van Deth, J. W., Montero, J. R., \& Westholm, A. (Eds.). Citizenship and involvement in European democracies: a comparative analysis. Routledge. Pp. 255-279.

Larsson Taghizadeh, J. 2016. Power from Below?: The Impact of Protests and Lobbying on School Closures in Sweden. PhD thesis. Uppsala University.

Larsson Taghizadeh, J. 2015. Quality over quantity. Technical information, interest advocacy and school closures in Sweden. Interest groups \& Advocacy, 4(2), 101-119.

Lohmann, S. 1993. A Signaling Model of Informative and Manipulative Political Action. American Political Science Review, 87(02), 319-333. http://dx.doi.org/10.2307/2939043

Luders, J. E. 2010. The civil rights movement and the logic of social change. Cambridge University Press. http://dx.doi.org/10.1017/cbo9780511817120

Mansbridge, J. 1992. 'A Deliberative Theory of Interest Representation', in M. Petracca (ed.), The Politics of Interest. Boulder CO: Westview, pp. 32-57.

Mansbridge, J., Hartz-Karp, J., Amengual, M., \& Gastil, J. 2006. Norms of deliberation: An inductive study. Journal of public deliberation, 2(1).

McAdam, D., \& Boudet, H. 2012. Putting social movements in theirplace:Explainingopposition to energyprojectsinthe United States, 2000-2005. Cambridge University Press. http://dx.doi.org/10.1017/cbo9781139105811

McCammon, H. J. 2009. Beyond frame resonance: The argumentative structure and persuasive capacity of twentieth-century US women's jury-rights frames. Mobilization: An International Quarterly, 14(1), 45-64.

McCammon, H. J., Muse, C. S., Newman, H. D., \& Terrell, T. M. 2007. Movement framing and discursive opportunity structures: The political successes of the US women's jury movements. American Sociological Review, 72(5), 725-749. http://dx.doi.org/10.1177/000312240707200504

McVeigh, R., Myers, D. J., \& Sikkink, D. 2004. Corn, Klansmen, and Coolidge: Structure and framing in social movements. Social Forces, 83(2), 653-690. http://dx.doi.org/10.1353/sof.2005.0019

Mendonça, R. F., \& Ercan, S. A. 2015. Deliberation and protest: strange bedfellows? Revealing the deliberative potential of 2013 protests in Turkey and Brazil. Policy Studies, 36(3), 267-282. http://dx.doi.org/10.1080/01442872.2015.1065970

Meyer, D. S., \& Minkoff, D. C. 2004. Conceptualizing political opportunity. Social forces, 82(4), 1457-1492. http://dx.doi.org/10.1353/sof.2004.0082 
Öberg, P., \& Uba, K. 2014. Civil Society Making Political Claims: Outcries, Interest Advocacy, and Deliberative Claims. Public Administration Review, 74(3), 413-422. http://dx.doi.org/10.1111/puar.12199

Ortiz, D., Myers, D., Walls, E., \& Diaz, M. E. 2005. Where do we stand with newspaper data? Mobilization: An International Quarterly, 10(3), 397-419.

Pan, Z., and G. M. Kosicki. 2001. "Framing as a Strategic Action in Publication Deliberation." In Framing Public Life, eds. Stephen D. Reese, Oscar H. Gandy, Jr., and August E. Grant. Hillsdale, NJ: Erlbaum, pp. 35-66.

Parkinson, J., \& Mansbridge, J. 2012. Deliberative systems: deliberative democracy at the large scale. Cambridge University Press. http://dx.doi.org/10.1017/cbo9781139178914

Piven, F. F., \& Cloward, R. A. 1979. Poor people's movements: Why they succeed, how they fail (Vol. 697). Vintage books.

Ström, K., \& Müller, W. C. 1999. "Political parties and hard choices." in Müller \& Ström (ed.) Policy, Office, or
Votes?: How Political Parties in Western Europe Make Hard Decisions, Cambridge university Press. pp.1-35.

Trumpy, A. J. 2008. Subject to negotiation: The mechanisms behind co-optation and corporate reform. Social Problems, 55(4), 480-500. http://dx.doi.org/10.1525/sp.2008.55.4.480

Uba, K. 2016. "Protest Against the School Closures in Sweden: Accepted by Politicians?" in Bosi, L., Giugni, M. and Uba, K. edited The Consequences of Social Movements, Cambridge University Press.

Uba, K. 2009. The contextual dependence of movement outcomes: a simplified meta-analysis. Mobilization: An International Quarterly, 14(4), 433-448.

Witten, K., Kearns, R., Lewis, N., Coster,H., \& McCreanor, T.2003. Educational restructuring from a community viewpoint: a case study of school closure from Invercargill, New Zealand. Environment and Planning C, 21(2), 203-224. http://dx.doi.org/10.1068/c05r

Young, I. M. 2001. Activist challenges to deliberative democracy. Political theory, 29(5), 670-690. http://dx.doi.org/10.1177/0090591701029005004
KATRIN UBA is Associate Professor at the Department of Government at Uppsala University, Sweden. Her research is focused on social movements and policy processes, particularly on the role that interests groups and protest mobilisation play in public policy making in developed and developing democracies. In some of her most recent research projects, she examined the political consequences of protests against school closures in Sweden and the outcomes of the mobilisation of right-wing radicals in Russia, as well as the mobilisation of protest in Sweden and citizens resilience at times of economic crises (EU FP7 funded Livewhat project). She has published in international peer-reviewed journals such as Public Administration Review, Western European Politics, Mobilization and Europe Asia Studies. 